NBER WORKING PAPER SERIES

FRENCH WINE AND THE U.S. BOYCOTT OF 2003:

DOES POLITICS REALLY AFFECT COMMERCE?

\author{
Orley Ashenfelter \\ Stephen Ciccarella \\ Howard J. Shatz \\ Working Paper 13258 \\ http://www.nber.org/papers/w13258
}

\author{
NATIONAL BUREAU OF ECONOMIC RESEARCH \\ 1050 Massachusetts Avenue \\ Cambridge, MA 02138 \\ July 2007
}

The authors thank the Public Policy Institute of California for partial funding of this research. The research for this article was conducted when Shatz was a research fellow at the Public Policy Institute of California. Any opinions expressed in this paper are those of the authors and do not necessarily represent the views of the RAND Corporation or its research clients or sponsors, the views of the staff, officers, or board of directors of the Public Policy Institute of California, or the views of the other institutions listed below. We are deeply indebted to Frank Vannerson of Mt. Lucas Management Corporation for data, and for many helpful discussions and useful comments. The views expressed herein are those of the author(s) and do not necessarily reflect the views of the National Bureau of Economic Research.

(C) 2007 by Orley Ashenfelter, Stephen Ciccarella, and Howard J. Shatz. All rights reserved. Short sections of text, not to exceed two paragraphs, may be quoted without explicit permission provided that full credit, including $\odot$ notice, is given to the source. 
French Wine and the U.S. Boycott of 2003: Does Politics Really Affect Commerce?

Orley Ashenfelter, Stephen Ciccarella, and Howard J. Shatz

NBER Working Paper No. 13258

July 2007

JEL No. D12,F14,L66,Q17

\begin{abstract}
In early 2003, France actively tried to thwart the plans of the Bush administration to build international support for a war to depose Iraqi ruler Saddam Hussein. In response, calls in the United States for a boycott of French products, wine in particular, rebounded through all forms of media. In the spring of 2003, French business people even reported that the boycott calls were hurting their U.S. sales. Using a dataset of sales of nearly 4,700 individual wine brands, we show that there actually was no boycott effect. Rather, sales of French wine dipped for two reasons. First, they experience a cyclical peak at holiday time, from November through early January, and the boycott was called during the February to May period. Second, sales of French wine have been in a secular decline in the United States. Sales in February through May 2003 merely stayed on trend. We contrast our results with other recent work that has found evidence of a boycott effect but that omits the holiday effect from several specifications. French wine producers may be having economic problems, but it is not because of their government's foreign policy.
\end{abstract}

Orley Ashenfelter

Industrial Relations Section

Firestone Library

Princeton University

Princeton, NJ 08544

and NBER

c6789@princeton.edu

Stephen Ciccarella

Economics Department

Cornell University

Ithaca, NY 14850

smc227@cornell.edu
Howard J. Shatz

RAND Corporation

1200 South Hayes Street

Arlington, VA 22202-5050

howard_shatz@rand.org 


\title{
French Wine and the U.S. Boycott of 2003: Does Politics Really Affect Commerce?*
}

\author{
Orley Ashenfelter ${ }^{\mathrm{a}}$, Stephen Ciccarella ${ }^{\mathrm{b}}$, Howard J. Shatz ${ }^{\mathrm{c}}$
}

\begin{abstract}
In early 2003, France actively tried to thwart the plans of the Bush administration to build international support for a war to depose Iraqi ruler Saddam Hussein. In response, calls in the United States for a boycott of French products, wine in particular, rebounded through all forms of media. In the spring of 2003, French business people even reported that the boycott calls were hurting their U.S. sales. Using a dataset of sales of nearly 4,700 individual wine brands, we show that there actually was no boycott effect. Rather, sales of French wine dipped for two reasons. First, they experience a cyclical peak at holiday time, from November through early January, and the boycott was called during the February to May period. Second, sales of French wine have been in a secular decline in the United States. Sales in February through May 2003 merely stayed on trend. We contrast our results with other recent work that has found evidence of a boycott effect but that omits the holiday effect from several specifications. French wine producers may be having economic problems, but it is not because of their government's foreign policy. (JEL classification: D12, F14, L66, Q17)
\end{abstract}

\section{Introduction}

Pressures to change consumer tastes and purchasing behavior abound. Some come from market participants, such as producers and merchants who engage in advertising and marketing campaigns. But nonmarket participants are also prominent, in particular the politicians and activists who encourage consumer boycotts for particular causes. Boycotts are alleged to have helped migrant farm workers in California gain increased pay and to have helped end the

\footnotetext{
* The authors thank the Public Policy Institute of California for partial funding of this research. The research for this article was conducted when Shatz was a research fellow at the Public Policy Institute of California. Any opinions expressed in this paper are those of the authors and do not necessarily represent the views of the RAND Corporation or its research clients or sponsors, the views of the staff, officers, or board of directors of the Public Policy Institute of California, or the views of the other institutions listed below. We are deeply indebted to Frank Vannerson of Mt. Lucas Management Corporation for data, and for many helpful discussions and useful comments.

${ }^{a}$ Economics Department, Industrial Relations Section, Princeton University, Princeton, New Jersey 08544-2098, Tel (609) 258-4040, Fax (609) 258-2907, email: c6789@Princeton.EDU

${ }^{\mathrm{b}}$ Economics Department, Cornell University, Ithaca, NY 14850, Tel (607) 232-2147, Fax (607) 255-2818, email: smc227@cornell.edu

${ }^{\mathrm{c}}$ RAND Corporation, 1200 South Hayes Street, Arlington, VA 22202-5050, Tel (703) 413-1100 x5184, Fax (703)

413-8111, email: howard_shatz@rand.org
} 
apartheid regime in South Africa. They have been declared against French products following a resumption of nuclear testing in the 1990s, and most recently they were declared by part of the Muslim world against Danish products several months after the publication of cartoons of the prophet Muhammad in a Danish newspaper.

Calls for a boycott can have one of three effects. Consumers can honor the boycott, leading to a decline in sales of the product being boycotted. They can ignore the boycott, leading to no change in sales. Or, expressing opposition to the goals of the boycott, they can increase their purchases, leading to increases in sales. In fact, this latter effect is alleged to have occurred regarding the boycott of Danish products in 2006 (Hitchens, 2006). Thus, the aggregate effect is an entirely empirical matter.

This paper studies the boycott issue by investigating U.S. consumer behavior during the run-up, major combat, and immediate post-combat lull of the Iraq War that started in 2003. France proved a tenacious opponent to U.S. plans to marshal a multinational force to invade Iraq and depose its dictator, Saddam Hussein, and calls for a boycott of French wine and other products rebounded throughout the United States. Emotions ran high. Taking a cue from the bandits of the Mexican mountains who eschewed government-sanctioned, peace-officer identification (Traven, 1934), one boycotter proclaimed on national television, "We don’t need your stinking wine” (Lou Dobbs Moneyline, 2003b).

We find that at first glance, the calls for a boycott did lead to a decline in French wine sales in the United States. However, at the time of the boycott, French wine sales had already 
been declining over a longer period, and just before the boycott period, sales of French wine had experienced a seasonal holiday peak. When the secular decline and seasonal effects are accounted for, there is no boycott effect. Our work builds on the previous work of Vannerson (2004) by using microdata on wine sales for nearly 4,700 brands in the United States and studying the effects of the boycott on the revenue share of French wine, the quantity share, the quantity, and the price. Our results differ from those of Chavis and Leslie (2006), and we explain those differences below.

In the next section, we review recent work on the French boycott. The subsequent section presents the key results using the microdata, and the section following contrasts this work with the opposite results found by Chavis and Leslie. A final section draws conclusions.

\section{Recent Work on the French Boycott of 2003}

The U.S. boycott of French wine was not the first faced by the French. In 1995, after the French military announced a series of nuclear tests in the South Pacific, Denmark embarked on a boycott of French products. There appears to have been remarkable unanimity. All Danish political parties signed a protest letter to the French government, and a Danish minister wrote a letter to his French counterpart, on behalf of the Danish government, to try to stop the tests. In addition, a major Danish retail chain stopped marketing French products and was joined by other Danish retailers.

Bentzen and Smith (2001) find a boycott effect at the end of 1995 and the beginning of 1996, even after taking account of seasonal components and a trend decline in the market share of 
French wine. They also find a possible longer-run effect through 1998. However, they do not reject the existence of price effects during 1995 and 1996.

The political situation in the United States in 2003 was quite different from that in Denmark in 1995 and 1996. Unlike in the Danish case, the United States was not united in its interest in punishing the French for their opposition to the Iraq War. Rather, the country was deeply divided over the policy, and therefore many people not only saw no need to punish the French, but rather saw buying French products as an opportunity to praise the French for their opposition to the proposed war.

Vannerson (2004) provided one of the first, if not the first, analyses regarding the U.S. boycott of French wines in 2003 by testing the following model

$$
W_{t}=\alpha+\beta_{1} B_{t}+\beta_{2} H_{t}+\beta_{3} T_{t}+\varepsilon_{t}
$$

In the equation, $W$ is the revenue share of French wine sales in the United States, in percentage points, $B$ is a dummy for the boycott period, $H$ is a seasonal dummy for the holiday period, and $T$ is a time trend. These are explained below.

The data are gathered from scanners in high volume supermarket chains in 64 major U.S. markets, and were provided by Information Resources, Inc. (IRI). They include dollar sales and prices organized by country of origin, type of wine (table, dessert, and fortified, for example), label information, and the market where sold. They run in 22 four-week blocks from September 10, 2001, through May 18, 2003. 
The data exclude wine sold in restaurants and wine specialty shops, a flaw because these are the venues where higher-end wines are sold more frequently, and the French have a stronger position in the high end. If anything, this should bias results in favor of finding a boycott effect. The use of supermarket scanner data also results in under-representation of states where supermarket sales of wines are limited or forbidden, in particular Massachusetts, New York, New Jersey, and Pennsylvania, although Massachusetts allows supermarket sales of alcohol in a restricted set of stores. Nonetheless, the data provide a consistent, accurate, and comprehensive account of most wine sold in the United States. Descriptive statistics are shown in Appendix Table 1.

Vannerson identified the boycott period as extending from February 2003 through May 2003, specifically January 27 through May 18. In his first test, he compared sales during that period to sales during the previous four four-week periods and found that sales in the boycott period were 0.56 percentage points lower -2.55 percent compared to 3.11 percent-a statistically significant difference (top of Table 1). The same holds true when all 22 periods are included (Table 1, column 2, a specification not in the original paper). The French revenue share in the boycott period was lower on average than in the previous 18 four-week periods.

\section{Table 1 about here}

However, French wine sales ordinarily increase in November, December, and January, a significant holiday period in the United States. To account for this, Vannerson added a holiday dummy for the three four-week periods from November 5, 2001, through January 27, 2002, and the three four-week periods from November 4, 2002, through January 26, 2003. In addition, 
French wine sales were trending downwards even before the boycott, so Vannerson added a time trend. Taking these two patterns into account, there is actually no boycott effect (Table 1, final column). The decrease in French revenue share of wine sales in the United States during the first part of 2003 resulted from the end of the cyclical holiday peak and the secular decline of sales of French wine.

This basic insight is robust to other measures of French wine sales. It may have been the case that fewer bottles of French wine were purchased during the boycott period, but that they were more expensive on average, leading to no effect on revenue share. Regressions using French quantity share as a dependent variable indicate that without a holiday indicator and a time trend the boycott appears to have been effective. However, when these are included, once again the estimated boycott coefficient becomes statistically insignificant (bottom of Table 1). This suggests that there was no boycott effect on the quantity of French wine sold in the United States.

In contrast, Chavis and Leslie (2006) do find a boycott effect, in particular, in their preferred specification, a 13 percent decline in U.S. sales of French wine over the first six months after the start of the war with Iraq. They use weekly microdata from IRI on prices and quantities by product and country of origin for December 2001 to November 2003 for wine sales in supermarkets and other general merchandise stores in four markets—Boston, Houston, Los Angeles, and San Diego. Although their data are weekly, they have the same disadvantages as the Vannerson database along with the added disadvantage of potentially being unrepresentative 
of the U.S. market as a whole. In addition, one of the markets, Boston, is severely underrepresented because wine sales there take place in supermarkets only on a limited basis.

There are other differences as well. Most important, using the same dummy variable approach as Vannerson, they define the boycott period as the first eight weeks after the start of the war, or March 17, 2003, through May 11, 2003. They then study the effects of the boycott on quantities and prices of French wine sold. In each specification, the boycott effect is negative and statistically significant. They also conduct the analysis using non-linear least squares and find similar results.

\section{New Results on the U.S. Boycott}

We build on the Vannerson paper by exploiting the microstructure of the IRI data. Nearly 4,700 brands of wine were sold throughout the United States from October 2001 through May 2003. Of these, 923 were French. Using these microdata provides a richer dataset, allows us to gain more precise estimates of coefficients, and reduces the possibility of aggregation bias that might arise from summing sales of all French wines. We test variations of the following relationship, an expanded version of equation (1).

$$
W_{i j t}=\alpha+\beta_{1} B_{t}+\beta_{2} H_{t}+\beta_{3} T_{j t}+\beta_{4} N_{i}+\beta_{5} M_{t}+\varepsilon_{i j t}
$$

$W$ is some measure of wine sales_-revenue share, natural log of quantity, quantity share, or natural log of price-for each wine $i$ from each country of origin $j$ in each of 22 four-week time periods $t$. $B$ is a dummy variable for the boycott period, the four four-week periods starting January 27, 2003, and is included only for observations on French wines. $H$ is a dummy for the holiday period, the three four-week periods starting November 5, 2001, and the three four-week 
periods starting November 4, 2002, and again is included only for observations on French wines. Following Chavis and Leslie (2006) and analogous to Vannerson (2004), $T$ is an origin-specific time trend for each country or region of origin of the wine (Vannerson tests French revenue share but does not include separate observations by country of origin and therefore uses one time trend rather than origin-specific time trends).

Among the other variables in equation (2), $N$ is a wine-specific dummy, allowing us to remove a significant amount of unobserved heterogeneity, such as label aesthetics, the public's perception of specific brands, and even general price level of the wine (although we do test a specification with price explicitly entered as an explanatory variable). $M$ is a month-specific dummy for each four-week period, and $\varepsilon$ is an error term. Origin countries and regions include Argentina, Australia, Austria, Bulgaria, California, Canada, Chile, France, Germany, Greece, Hungary, Ireland, Israel, Italy, Japan, Lebanon, Mexico, Morocco, Netherlands, New York, New Zealand, Oregon and Washington, Portugal, Romania, Russia, South Africa, South America, Spain, and Yugoslavia.

Columns 1 and 2 of Table 2 show the key results. Only coefficients for the boycott dummy are shown. Column 1 is comparable to Table 1 , column 1 , in which no holiday dummy or time trend is included. The results seem to provide strong evidence of a boycott effect, although smaller than that indicated in Table 1 when measured at the mean revenue share. In Table 1, the boycott reduced the French revenue share by almost 20 percent ( 0.56 divided by 2.83), but in Table 2 it reduced the French brand-specific revenue share by only 3 percent ( 0.659 divided by 21.31; all revenue shares are multiplied by 100,000). At the median, however, the size of the effect is the 
opposite. In Table 1, the boycott reduced the French revenue share by the same 20 percent $(0.56$ divided by 2.85), but in Table 2 it reduced the French brand-specific revenue share by almost 1,000 percent (0.659 divided by 0.061$)$.

\section{Table 2 about here}

Results for quantity and quantity shares as dependent variables similarly indicate a boycott effect, and all are statistically significant at the 1 percent level. However, these results do not take account of the special holiday effect experienced by French wine or the secular decline in sales of French wine. In fact, many varieties of Champagne could have experienced dramatic decreases in the late winter and early spring, having been bought in December for New Year and then not purchased again until a year later.

When holiday and trend effects are included, the boycott effect disappears (column 2). In all cases - the revenue share of each brand, the quantity of each brand, and the quantity share of each brand - sales are unaffected by the boycott. In fact, the point estimates for the effect of the boycott on revenue share and quantity share actually are positive, although these coefficients are not statistically significant.

In their paper, Chavis and Leslie try specifications in which they include only brands that have strictly positive sales in their boycott and comparison periods. We follow their lead in columns 3 through 6, including all brands that have strictly positive sales in all periods in the regressions. In Appendix Table 2 we show the same results when all observations with strictly positive sales 
are included, even though observations for those same brands may have zero sales in some months, rather than the Table 2 regressions of only brands with strictly positive sales over the entire period of analysis.

The results confirm the basic findings. In most cases without the holiday dummy or the time trend, the boycott appears to have affected sales of French wines in the United States. Oddly, the boycott appears to be related to increased price, which Chavis and Leslie also found. However, in every case with the holiday dummy and time trend included, there is no boycott effect, except in the case of quantities, and here the boycott is related to an increase in the quantity of French wine bought.

Although the results are similar to those using the full dataset, we do not agree that the observations with zero sales should be omitted. Chavis and Leslie justify this by noting that zero sales in any one period might result from stocking decisions of retailers or distributors, rather than consumers' choices. However, zero sales might also result from consumers' choices, and thus including them provides valuable information. Furthermore, if brands were being withheld, the number of brands with zero sales should be higher during the boycott period compared to earlier periods. However, this was not the case. For all of the 22 periods, the number of French brands with zero sales ranged from 504 to 518, with the median 510.5 (the average of 510 for the $11^{\text {th }}$ observation and 511 for the $12^{\text {th }}$ observation when ranked from low to high). French brands with zero sales during the boycott period totaled 509 (period 22), 510 (period 21), 511 (period 20), and 514 (period 19). The number of brands with zero sales actually decreased during the boycott period, hardly evidence of negative stocking decisions by distributors or retailers. 


\section{Boycott Effects and the Boycott Period}

One other important difference between the analysis so far and that of Chavis and Leslie is the designated boycott period. They use two methods. In the first, they limit the boycott period to the first eight weeks after the start of the war. President George W. Bush delivered an ultimatum on March 17, 2003, that Saddam Hussein and his sons had 48 hours to leave Iraq. The war, dubbed Operation Iraqi Freedom, began on March 20 with an air strike on Saddam Hussein’s compound (Airman, 2003). Because their data are weekly, Chavis and Leslie designate the boycott period as March 17 through May 11.

In their second method, a nonlinear specification, they use newspaper reports of the boycott and discussions of the boycott by Bill O’Reilly on The O'Reilly Factor, a Fox News show, as a proxy for calls for the boycott. This method does not assume a boycott period, but instead yields an estimate of how long a boycott lasted. In this method, they include a holiday dummy, although in their linear specification they do not. We do not address their nonlinear specification further.

How long was the boycott period? Available evidence indicates that it started in midFebruary and was in full swing by mid-March, a period omitted from the Chavis and Leslie analysis. The peak moments of tension may well have occurred in early March. On March 5, France and Russia, which both hold veto power in the United Nations Security Council, and Germany announced that they would not allow a United Nations Security Council resolution authorizing the use of force against Iraq (The New York Times, 2003). French Foreign Minister Dominique de Villepin reiterated this on March 7, backed up by Russia and China, which also 
holds veto power (Barringer, 2003). And on March 10 in Paris, French President Jacques Chirac announced that France would veto a United Nations resolution authorizing the use of force, “whatever the circumstances” (Sciolino, 2003).

To further explore the timing of the boycott, we conducted a Nexis search using the string "wine AND boycott" for major newspapers and transcripts during the period November 1, 2002, to June 30, 2003. Lists of media included in these groups appear in Appendix Table 4. In both cases, we excluded all non-U.S. sources. As an aside, we note that the first time the term "freedom fries" appeared as a substitute for "French fries" in a major newspaper was February 20, 2003 (Kiely, 2003) and the first time it appeared in a transcript was February 17, 2003 (Syler, 2003).

The pattern from both sources is clear. Between November 2002 and June 2003, wine and boycott in the context of a boycott of French goods were mentioned in 187 newspaper articles or editorials. None of these mentions occurred in November, December, or January. The first mention occurred on February 13 in The Boston Herald (Gatlin, 2003). There were 23 articles in February, 80 in March, 54 in April, 20 in May, and only 10 in June.

Likewise, between November 2002 and June 2003, wine and boycott were mentioned in 173 transcripts in relation to France and the Iraq war. In November, December, and January, there were no references to wine and boycott related to France. In February, there were 49, and this rose to 65 in March. The number fell to 40 in April, 16 in May, and only three in June. Bill O’Reilly first mentioned the boycott on February 24. Although hardly scientific, these numbers 
suggest the boycott was on the public's mind in February and that talk of the boycott peaked in March.

The content of these articles and transcripts also suggests the boycott started well before the start of the Iraq War. As early as February 13, it was announced that U.S. House of Representatives Speaker Dennis Hastert wanted to put orange labels on French wine (Lou Dobbs Moneyline, 2003a). Larry Gatlin in the Boston Herald on the same day wrote about the reactions of wine and food merchants to a consumer backlash that had supposedly already started. On February 26, it was reported that Pennsylvania State Representative Stephen Barrar was proposing a resolution that would ask the Pennsylvania Liquor Control Board to boycott French wine and liquor (KYW-TV Eyewitness News, 2003).

To further measure the potential for boycott action, we searched a nonrandom set of popular warbloggers, the usually libertarian or conservative but sometimes liberal webloggers who supported the war effort. An important mention can be found on Instapundit.com, authored by University of Tennessee Law Professor Glenn Reynolds, known by some as the blogfather because of his high web traffic and sizable influence among bloggers. On February 10, 2003, he reported hearing from one reader that perhaps the time to start boycotting French products had arrived, and he announced that he "had already started buying Australian, Argentine and Chilean wines in preference to the French wines.” On February 11, the message was a little saltier. One reader from Dayton, Ohio, wrote that he was about to buy a bottle of French wine when a man next to him "looking at the same wine said, '[expletive deleted] the French, I wouldn't drink it if it were free!' and picked up another bottle of wine, Aussie I think, glared at me and walked 
away. I thought to myself, 'yep, me too pal, with barbed wire’ and grabbed an Aussie bottle myself” (Instapundit.com, 2003).

Indeed, that specific post led Australian wag Tim Blair, then a columnist for The Bulletin, an Australian newspaper, and an independent blogger (TimBlair.net), to encourage Australian wineries on February 19 to move quickly into the newfound opportunity. "Attention, Australian wine exporters: the marketing opportunity of the century presents itself in the United States,” he wrote, “where French and German weasel wines are now shunned” (Blair, 2003).

Other blogs show similar evidence of boycott action before the start of the Iraq War. On March 6, proprietor Charles Johnson of the popular Little Green Footballs blog passed along an announcement for a demonstration to take place in Los Angeles in which people were to dump bottles of French wine in the gutter (Little Green Footballs, 2003). In fact, by March 26, Jeff Jarvis, author of the Buzz Machine blog, declared the boycott passé: "I see that NewsMax is not only spamming us with Boycott France popunder ads, they’re now placing Boycott France ads in at least the New York Times. That fight is so old already it's out. France is so... so... pre-war” (Jarvis, 2003).

Despite that, we now investigate sales of French wine in the United States as if the boycott started after the beginning of the Iraq War and lasted only two months. To start, we repeat the regressions of Table 1 but designate the boycott period as March 24 to May 18, the closest we can come to the Chavis and Leslie period of March 17 to May 11 (Table 3). As expected, without a holiday dummy or a time trend, the estimate of the boycott effect is negative and statistically significant. However, in contrast to the results using a four-month boycott period, when the holiday dummy and time trends are added, the boycott effect remains negative and statistically significant, as Chavis and Leslie found. 


\section{Table 3 about here}

This may actually be a boycott effect, but not quite the way the boycotters intended. When the boycott dummy is omitted from the regression, but the holiday dummy and the time trend are included, actual purchases for the period January 27 to February 23 are well above their predicted value, the largest underprediction for all 22 observations (Figure 1). There is evidence that this was also a time when people were actually overpurchasing French wines to protest against the boycott and the proposed war. A posting on Gawker, a popular Manhattan media news and gossip web site and part of Nick Denton’s Gawker Media empire, mentioned an antiwar protest on February 15: “I’ll probably protest the war by staying indoors and consuming French products, but should you decide to brave the cold, here's a map and logistics guide” (Gawker, 2003). It appears that people might have shifted their purchases to February, with a corresponding drop in purchases in April and May.

\section{Figure 1 about here}

In fact, when we separate all four potential boycott periods, the four-week periods from January 27 to May 18, 2003, we find this is exactly what happened (Table 4). Without the holiday dummy and time trend, coefficients for the last three four-week boycott periods are negative and statistically significant when the French revenue share during these periods is compared to that of the four four-month periods running from October 7, 2002, to January 26, 2003 (column 1). Furthermore, the coefficients for the last two four-week boycott periods are 
negative and significant when all 22 four-week periods are included (column 2). However, when the holiday dummy and time trend variables are included in the full 22-observation specification, the boycott effect for the period January 27 to February 23 is large and positive, as suggested by the residual plot of Figure 1, although significant at only the 10 percent level. Boycott effects for the final two periods, March 24 to April 20 and April 21 to May 18, are negative but not statistically significant at all.

\section{Table 4 and Table 5 about here}

Finally, we subject the full brand-level dataset to the analysis using only a two-month boycott period (Table 5). We use a specification as close as possible to that of Chavis and Leslie, omitting the holiday dummy from column 2 (it is included in Table 2, column 2). Even without the holiday dummy, but with the time trend, when all observations are included, including those with zero values, the boycott effect is not significant (column 2). The effect on revenue share is negative, but with a t-statistic of -1.04 and a p-value of 0.3 . The effect on quantity is positive, but it is negative on quantity share, and in neither specification is it statistically significant.

Columns 3 through 6 show the same results with only brands that have positive sales in all periods, for purposes of comparison with Chavis and Leslie (regressions when all observations with strictly positive sales are included, even though observations for those same brands may have zero sales in some months, are shown in Appendix Table 3). Results are again similar to those of Table 2, with one important exception. The regression of revenue share with origin-specific time trends shows a negative and large boycott effect (column 5). Although this is significant at only the 10 percent level, it is troubling. 
However, there is one factor missing. As noted previously, French wines experience a seasonal holiday sales increase, and the regressions in columns 1 through 5 in this table do not include an indicator for the holiday period. When that indicator is added, in column 6 , the estimate of the boycott effect decreases in magnitude and becomes statistically insignificant. There is no boycott effect, even when the boycott period is designated as March 24 to May 18, the two months after the start of the Iraq War.

\section{Conclusion}

On April 16, 2003, the same day that General Tommy Franks, commander of U.S. Central Command, entered Baghdad, the Washington Post reported that the boycott was having a painful effect on the French. "American importers of French wine are reporting sharp drops in sales in the past two months, and other French products also have been affected. The [French] Federation of Wine Exporters has called a meeting Thursday to discuss how to respond" (McCartney, 2003).

The data simply do not support this conclusion, however. There is no evidence that at the retail level, American consumers as a whole turned their backs on French wines at a faster rate than they had already been turning them. There were even news reports around the same time that the boycott had not affected sales:

In fact, many of the anti-France movements have barely caused a ripple. Sales of French wines aren't suffering even though some bottles have been dumped down the drain. And while some state legislatures threatened to boycott French-owned businesses, it lasted about as long as it took them to discover that French-owned companies in their own back yard provide thousands of jobs and products for their residents (Dang, 2003). 
Interestingly, the boycott does not appear in the trade data either. U.S. imports of French wine in February 2003 were 36 percent higher than they were in February 2002. The year-onyear increase was 43 percent in March, 26 percent in April, and a huge 50 percent in May, \$97 million in 2003 versus \$65 million in 2002 (U.S. International Trade Commission, 2006).

We cannot rule out the possibility that the boycott had a very large effect on sales of French wine. We can, however, rule out the claim that there was a very large effect in one direction — downward. Rather, with the U.S. deeply divided over the wisdom of engaging in the Iraq War, the boycott threats might have had both large negative and positive effects, encouraging pro-war consumers to modify their purchases away from French goods, and encouraging anti-war consumers to modify their purchases towards French goods.

On March 14, three days before Bush delivered his ultimatum, Middletown, Connecticut, Navy veteran Bill Earls wrote that he bought a case of French wine in support of the French. “The French are making some good points and being maligned for it” (Earls, 2003). Around the same time, Senator Evan Bayh (D-Indiana), when asked on The O'Reilly Factor whether he would honor the boycott, said, "Well, I'm not going to be running out to buy any French wine in the near future. I'll say that” (The O'Reilly Factor, 2003). The most we can say is that the aggregate effect represented no change in preferences, a surprising result given that even the French themselves thought that the boycott had been effective.

Besides expressing anti-war sentiments, there may have been many other reasons to buy French wines. They communicate a modicum of savoir-faire, and they are often cheaper than comparable California wines. Perhaps people stopped buying Dannon yogurt instead. 


\section{References}

Airman: Magazine of America's Air Force (2003). Operation Iraqi freedom chronology. June, web edition, available at http://www.af.mil/news/airman/0603/oifupsb1.html (as of June 23, 2006).

Barringer, F. (2003). Threats and responses: United Nations; U.N. split widens as allies dismiss deadline on Iraq. The New York Times, March 8, 1.

Bentzen, J. and Smith, V. (2001). Did the French nuclear tests under the Muroroa atoll affect the export of French wine to Denmark? Department of Economics, Aarhus School of Business, Denmark, May 14.

Blair, T. (2003). Bin of the Brave. The Bulletin (Australia), February 19.

Chavis, L. and Leslie. P. (2006). Consumer boycotts: the impact of the Iraq war on French wine sales in the U.S.. National Bureau of Economic Research Working Paper 11981. Cambridge, Massachusetts.

Dang, D.T (2003). Pardon their French, they feed the marines; Contract: Sodexho Inc., Under contract to feed U.S. marines, is under attack for its French connection, but the marines at camp Lejeune keep right on lining up for chow,” The Baltimore Sun, April 13, 1D.

Earls, B. (2003). I’m buying French. Hartford Courant, March 14, A15.

Gatlin, L. (2003). French still sells, despite war stance. The Boston Herald, February 13, 41.

Gawker (2003). Protest map and logistics. Gawker.com, February 15.

Hitchens, C. (2003). The Jordan connection: why Amman helped track down Zarqawi. Slate, June 12.

Instapundit (2003). Posts of February 10 and February 11, http://instapundit.com.

Jarvis, J. (2003). Remember France? Post of March 26, http://www.buzzmachine.com.

Kiely, K. (2003). Angry Americans aim ire at France. USA Today, February 20, 8A.

KYW-TV Eyewitness News (2003). French Wine Boycott. Video Monitoring Services of America, February 26.

Little Green Footballs (2003). Our Favorite Pastime, Post of March 6, http://www.littlegreenfootballs.com/weblog.

Lou Dobbs Moneyline (2003a). Lou Dobbs Moneyline for March 27, 2003, CNN. 
Lou Dobbs Moneyline (2003b). Troops in place for war with Iraq. February 13, CNN.

McCartney, R.J. (2003). U.S. boycott being felt, French say; wine sales off sharply; other products affected. The Washington Post, April 16, A32.

The New York Times (2003). Threats and responses; words of refusal: three nations say no. March 6, 16.

The O’Reilly Factor (2003). Interview with Senator Evan Bayh. Fox News Network, March 17.

Sciolino, E. (2003). Threats and responses: discord; France to veto resolution on Iraq war, Chirac says. The New York Times, March 11, 10.

Syler, R. (2003). Restaurant changing its name of French fries to freedom fries. The Early Show, CBS News Transcripts, February 17.

Traven, B. (1934). The Treasure of the Sierra Madre. London: Chatto \& Windus.

U.S. International Trade Commission (2006). HTS 2204: Wine of fresh grapes, including fortified wines; grape must (having an alcoholic strength by volume exceeding $0.5 \%$ vol.) NESOI, customs value by HTS number and country name for all countries, U.S. imports for consumption. DataWeb Version 2.7.4, Washington, D.C., accessed June 23, 2006.

Vannerson, F. (2004). Wine, francophobia and boycotts. Princeton, New Jersey, available at www.liquidasset.com (as of June 2006). 
Table 1

Estimated Boycott Effect, Aggregated Data and Four-Month Boycott Period

\begin{tabular}{|c|c|c|c|}
\hline & $\begin{array}{c}\text { Boycott and } \\
\text { Comparison Periods } \\
\text { (1) }\end{array}$ & $\begin{array}{l}\text { Entire 22-Month } \\
\text { Period } \\
\text { (2) }\end{array}$ & $\begin{array}{l}\text { Entire 22-Month } \\
\text { Period } \\
\text { (3) }\end{array}$ \\
\hline \multicolumn{4}{|c|}{ Dependent Variable - French Revenue Share } \\
\hline Boycott Dummy & $\begin{array}{l}-0.560^{* *} \\
(0.193)\end{array}$ & $\begin{array}{l}-0.585^{* * *} \\
(0.167)\end{array}$ & $\begin{array}{l}-0.007 \\
(0.117)\end{array}$ \\
\hline Holiday Dummy & & & $\begin{array}{l}0.488^{* * *} \\
(0.075)\end{array}$ \\
\hline Time Trend & & & $\begin{array}{l}-0.038^{* * *} \\
(0.007)\end{array}$ \\
\hline Adjusted $\mathrm{R}^{2}$ & 0.514 & 0.349 & 0.841 \\
\hline \multicolumn{4}{|c|}{ Dependent Variable - French Quantity Share } \\
\hline Boycott Dummy & $\begin{array}{l}-0.493^{* *} \\
(0.170)\end{array}$ & $\begin{array}{l}-0.495^{* * *} \\
(0.137)\end{array}$ & $\begin{array}{l}-0.038 \\
(0.103)\end{array}$ \\
\hline Holiday Dummy & & & $\begin{array}{l}0.394 * * * \\
(0.067)\end{array}$ \\
\hline Time Trend & & & $\begin{array}{l}-0.030 * * * \\
(0.006)\end{array}$ \\
\hline Adjusted $\mathrm{R}^{2}$ & 0.515 & 0.365 & 0.818 \\
\hline $\mathrm{N}$ & 8 & 22 & 22 \\
\hline \multicolumn{4}{|c|}{$\begin{array}{l}\text { Notes: Boycott period is defined as January 27, } 2003 \text { to May } 18,2003 \text {. Comparison period is defined } \\
\text { as October 7, } 2002 \text { to January } 26,2003 \text {. Holiday period in column } 1 \text { is November 4, 2002, through January 26, } \\
\text { 2003. Holiday period in columns } 2 \text { and } 3 \text { is November 5, 2001, through January 27, 2002, and the column } 1 \\
\text { holiday period. Standard errors are in parentheses. *, **, and *** indicate the estimate is statistically significant } \\
\text { at the ten-, five-, or one-percent level, respectively. }\end{array}$} \\
\hline
\end{tabular}




\section{Estimated Boycott Effect, Individual Brand Data and Four-Month Boycott Period}

\begin{tabular}{|c|c|c|c|c|c|c|}
\hline & $\begin{array}{c}\text { Boycott and } \\
\text { Comparison } \\
\text { Periods } \\
\text { (1) }\end{array}$ & $\begin{array}{l}\text { Entire } \\
\text { 22-Month } \\
\text { Period } \\
\text { (2) }\end{array}$ & $\begin{array}{l}\text { Boycott and } \\
\text { Comparison } \\
\text { Periods } \\
\text { (3) }\end{array}$ & $\begin{array}{l}\text { Boycott and } \\
\text { Comparison } \\
\text { Periods } \\
\text { (4) }\end{array}$ & $\begin{array}{l}\text { Entire } \\
\text { 22-Month } \\
\text { Period } \\
\text { (5) }\end{array}$ & $\begin{array}{c}\text { Entire } \\
\text { 22-Month } \\
\text { Period } \\
\text { (6) }\end{array}$ \\
\hline \multicolumn{7}{|c|}{ Dependent Variable - Revenue Share } \\
\hline Boycott dummy & $\begin{array}{c}-0.659 * * * \\
(0.229)\end{array}$ & $\begin{array}{c}0.556 \\
(0.875)\end{array}$ & $\begin{array}{l}-1.57 * * * \\
(0.518)\end{array}$ & & $\begin{array}{l}-1.56 \\
(1.46)\end{array}$ & $\begin{array}{c}1.79 \\
(1.78)\end{array}$ \\
\hline Adjusted $\mathrm{R}^{2}$ & 0.974 & 0.975 & 0.982 & & 0.980 & 0.980 \\
\hline \multicolumn{7}{|c|}{ Dependent Variable - $\ln ($ Quantity) } \\
\hline Boycott dummy & $\begin{array}{l}-0.134^{* * *} \\
(0.025)\end{array}$ & $\begin{array}{l}-0.004 \\
(0.059)\end{array}$ & $\begin{array}{l}-0.095^{* * *} \\
(0.032)\end{array}$ & $\begin{array}{l}-0.084^{* * *} \\
(0.031)\end{array}$ & $\begin{array}{l}0.125 * * \\
(0.062)\end{array}$ & $\begin{array}{l}0.148 * * \\
(0.074)\end{array}$ \\
\hline Adjusted $\mathrm{R}^{2}$ & 0.909 & 0.914 & 0.935 & 0.939 & 0.934 & 0.934 \\
\hline \multicolumn{7}{|c|}{ Dependent Variable - Quantity Share } \\
\hline Boycott dummy & $\begin{array}{c}-0.672 * * \\
(0.334)\end{array}$ & $\begin{array}{r}0.501 \\
(0.803)\end{array}$ & $\begin{array}{l}-0.728 \\
(0.684)\end{array}$ & & $\begin{array}{r}-1.28 \\
(1.36)\end{array}$ & $\begin{array}{l}1.56 \\
(1.70)\end{array}$ \\
\hline Adjusted $\mathrm{R}^{2}$ & 0.981 & 0.981 & 0.986 & & 0.984 & 0.984 \\
\hline \multicolumn{7}{|c|}{ Dependent Variable - $\ln$ (Price) } \\
\hline Boycott dummy & & & $\begin{array}{c}0.008^{*} \\
(0.005)\end{array}$ & & & \\
\hline Adjusted $\mathrm{R}^{2}$ & & & 0.944 & & & \\
\hline $\begin{array}{l}\text { France-specific holiday } \\
\text { dummy }\end{array}$ & No & Yes & No & No & No & Yes \\
\hline Origin-specific time trends & No & Yes & No & No & Yes & Yes \\
\hline Quantity $>0$ in all months & No & No & Yes & Yes & Yes & Yes \\
\hline Price on RHS & No & No & No & Yes & No & No \\
\hline $\mathrm{N}$ & 37,536 & 103,224 & 16,992 & 16,992 & 46,728 & 46,728 \\
\hline
\end{tabular}

Notes: Boycott period is defined as January 27, 2003 to May 18, 2003. Comparison period is defined as January 28, 2002 to May 19, 2002. Boycott dummy equals one for French wine during the boycott period. Holiday period in columns 1, 3, and 4 is November 4, 2002, through January 26, 2003. Holiday period in columns 2, 5, and 6 is November 5, 2001, through January 27, 2002, and the column 1, 3, and 4 holiday period. Quantity shares and revenue shares are multiplied by 100,000. Following Chavis and Leslie (2006), in the log of quantity regressions of columns 1 and 2 we add a 1 to every quantity for every brand in order not to lose those brands with zero sales in any given period. Heteroscedasticity-robust standard errors are in parentheses. *,**, and *** indicate the estimate is statistically significant at the ten-, five-, or one-percent level, respectively. All regressions include wine and month fixed effects. 
Table 3

Estimated Boycott Effect Using Aggregated Data and Two-Month Boycott Period

\begin{tabular}{|c|c|c|c|}
\hline & $\begin{array}{c}\text { Boycott and } \\
\text { Comparison Periods } \\
\text { (1) }\end{array}$ & $\begin{array}{l}\text { Entire 22-Month } \\
\text { Period } \\
\text { (2) }\end{array}$ & $\begin{array}{l}\text { Entire 22-Month } \\
\text { Period } \\
\text { (3) }\end{array}$ \\
\hline \multicolumn{4}{|c|}{ Dependent Variable - French Revenue Share } \\
\hline Boycott Dummy & $\begin{array}{l}-0.690^{* *} \\
(0.200)\end{array}$ & $\begin{array}{l}-0.788^{* * *} \\
(0.224)\end{array}$ & $\begin{array}{l}-0.305^{* *} \\
(0.108)\end{array}$ \\
\hline Holiday Dummy & & & $\begin{array}{l}0.460^{* * *} \\
(0.061)\end{array}$ \\
\hline Time Trend & & & $\begin{array}{l}-0.031^{* * *} \\
(0.005)\end{array}$ \\
\hline Adjusted $\mathrm{R}^{2}$ & 0.608 & 0.352 & 0.890 \\
\hline \multicolumn{4}{|c|}{ Dependent Variable - French Quantity Share } \\
\hline Boycott Dummy & $\begin{array}{l}-0.618^{* *} \\
(0.169)\end{array}$ & $\begin{array}{l}-0.685^{* * *} \\
(0.180)\end{array}$ & $\begin{array}{l}-0.304^{* * *} \\
(0.090)\end{array}$ \\
\hline Holiday Dummy & & & $\begin{array}{l}0.372 * * * \\
(0.051)\end{array}$ \\
\hline Time Trend & & & $\begin{array}{l}-0.024^{* * *} \\
(0.004)\end{array}$ \\
\hline Adjusted $\mathrm{R}^{2}$ & 0.639 & 0.392 & 0.888 \\
\hline $\mathrm{N}$ & 8 & 22 & 22 \\
\hline
\end{tabular}

Notes: Boycott period is defined as March 24, 2003 to May 18, 2003. Comparison period is defined as October 7, 2002 to January 26, 2003. Holiday period in column 1 is November 4, 2002, through January 26, 2003. Holiday period in columns 2 and 3 is November 5, 2001, through January 27, 2002, and the column 1 holiday period. Standard errors are in parentheses. *, **, and *** indicate the estimate is statistically significant at the ten-, five-, or one-percent level, respectively. 


\section{Table 4}

\section{Estimated Monthly Boycott Effect Using Aggregated Data and Four-Month Boycott Period, with Months Separately Identified}

\begin{tabular}{|c|c|c|c|}
\hline & $\begin{array}{c}\text { Boycott and } \\
\text { Comparison Periods } \\
\text { (1) }\end{array}$ & $\begin{array}{l}\text { Entire 22-Month } \\
\text { Period } \\
\text { (2) }\end{array}$ & $\begin{array}{l}\text { Entire 22-Month } \\
\text { Period } \\
\text { (3) }\end{array}$ \\
\hline \multicolumn{4}{|c|}{ Dependent Variable - French Revenue Share } \\
\hline Month 1 Dummy & $\begin{array}{l}-0.230 \\
(0.127)\end{array}$ & $\begin{array}{l}-0.223 \\
(0.313)\end{array}$ & $\begin{array}{l}0.280 * \\
(0.137)\end{array}$ \\
\hline Month 2 Dummy & $\begin{array}{l}-0.480 * * \\
(0.127)\end{array}$ & $\begin{array}{l}-0.473 \\
(0.313)\end{array}$ & $\begin{array}{l}0.066 \\
(0.139)\end{array}$ \\
\hline Month 3 Dummy & $\begin{array}{l}-0.810^{* * *} \\
(0.127)\end{array}$ & $\begin{array}{l}-0.803 * * \\
(0.313)\end{array}$ & $\begin{array}{l}-0.228 \\
(0.193)\end{array}$ \\
\hline Month 4 Dummy & $\begin{array}{l}-0.850^{* * *} \\
(0.127)\end{array}$ & $\begin{array}{l}-0.843^{* *} \\
(0.313)\end{array}$ & $\begin{array}{l}-0.232 \\
(0.145)\end{array}$ \\
\hline Holiday Dummy & & & $\begin{array}{l}0.485^{* * *} \\
(0.061)\end{array}$ \\
\hline Time Trend & & & $\begin{array}{l}-0.036^{* * * *} \\
(0.006)\end{array}$ \\
\hline $\begin{array}{l}\text { Joint Significance of } \\
\text { Month Dummies } \\
\text { (F-Statistic) }\end{array}$ & $18.46^{* *}$ & $3.72 * *$ & $3.16^{* *}$ \\
\hline $\mathrm{N}$ & 8 & 22 & 22 \\
\hline Adjusted $\mathrm{R}^{2}$ & 0.909 & 0.342 & 0.897 \\
\hline \multicolumn{4}{|c|}{$\begin{array}{l}\text { Notes: Boycott period is defined as January 27, } 2003 \text { to May 18, 2003. Comparison period is defined as } \\
\text { October 7, } 2002 \text { to January 26, 2003. "Month } 1 \text { Dummy" corresponds to the four-week period, January } \\
\text { 27, } 2003 \text { to February 23, 2003; “Month } 2 \text { Dummy" to the four-week period, February 24, } 2003 \text { to March } \\
\text { 23, } 2003 \text {; "Month } 3 \text { Dummy" to the four-week period, March 24, } 2003 \text { to April } 20,2003 \text {; and "Month } 4 \\
\text { Dummy" to the four-week period, April 21, } 2003 \text { to May } 18,2003 \text {. Holiday period in column } 1 \text { is } \\
\text { November 4, 2002, through January 26, 2003. Holiday period in columns } 2 \text { and } 3 \text { is November } 5,2001 \text {, } \\
\text { through January 27, 2002, and the column } 1 \text { holiday period. *, **, and *** indicate the estimate is } \\
\text { statistically significant at the ten-, five-, or one-percent level, respectively. Heteroscedasticity-robust } \\
\text { standard errors are in parentheses. }\end{array}$} \\
\hline
\end{tabular}


Table 5

\section{Estimated Boycott Effect Using Individual Brand Data and Two-Month Boycott Period}

\begin{tabular}{|c|c|c|c|c|c|c|}
\hline & $\begin{array}{c}\text { Boycott and } \\
\text { Comparison } \\
\text { Periods } \\
\text { (1) }\end{array}$ & $\begin{array}{c}\text { Entire } \\
\text { 22-Month } \\
\text { Period } \\
\text { (2) }\end{array}$ & $\begin{array}{c}\text { Boycott and } \\
\text { Comparison } \\
\text { Periods } \\
\text { (3) }\end{array}$ & $\begin{array}{c}\text { Boycott and } \\
\text { Comparison } \\
\text { Periods } \\
\text { (4) }\end{array}$ & $\begin{array}{c}\text { Entire } \\
\text { 22-Month } \\
\text { Period } \\
\text { (5) }\end{array}$ & $\begin{array}{c}\text { Entire } \\
\text { 22-Month } \\
\text { Period } \\
\text { (6) }\end{array}$ \\
\hline \multicolumn{7}{|c|}{ Dependent Variable - Revenue Share } \\
\hline Boycott dummy & $\begin{array}{l}-0.949 * \\
(0.554)\end{array}$ & $\begin{array}{l}-0.938 \\
(0.900)\end{array}$ & $\begin{array}{r}-1.07 \\
(1.04)\end{array}$ & & $\begin{array}{l}-3.12^{*} \\
(1.75)\end{array}$ & $\begin{array}{r}-2.00 \\
(1.79)\end{array}$ \\
\hline Adjusted $\mathrm{R}^{2}$ & 0.970 & 0.975 & 0.980 & & 0.980 & 0.980 \\
\hline \multicolumn{7}{|c|}{ Dependent Variable - In(Quantity) } \\
\hline Boycott dummy & $\begin{array}{l}-0.178^{* * *} \\
(0.036)\end{array}$ & $\begin{array}{c}0.002 \\
(0.055)\end{array}$ & $\begin{array}{l}-0.180 * * * \\
(0.045)\end{array}$ & $\begin{array}{l}-0.162^{* * *} \\
(0.044)\end{array}$ & $\begin{array}{l}-0.066 \\
(0.067)\end{array}$ & $\begin{array}{l}-0.075 \\
(0.068)\end{array}$ \\
\hline Adjusted $\mathrm{R}^{2}$ & 0.898 & 0.914 & 0.933 & 0.937 & 0.934 & 0.934 \\
\hline \multicolumn{7}{|c|}{ Dependent Variable - Quantity Share } \\
\hline Boycott dummy & $\begin{array}{l}-0.874^{*} \\
(0.520)\end{array}$ & $\begin{array}{l}-0.854 \\
(0.819)\end{array}$ & $\begin{array}{l}-1.04 \\
(1.03)\end{array}$ & & $\begin{array}{l}-2.66 \\
(1.68)\end{array}$ & $\begin{array}{r}-1.72 \\
(1.71)\end{array}$ \\
\hline Adjusted $\mathrm{R}^{2}$ & 0.977 & 0.981 & 0.983 & & 0.984 & 0.984 \\
\hline \multicolumn{7}{|c|}{ Dependent Variable - $\ln$ (Price) } \\
\hline Boycott dummy & \multicolumn{3}{|r|}{$\begin{array}{l}0.014 * * \\
(0.007)\end{array}$} & & & \\
\hline \multicolumn{2}{|l|}{ Adjusted $\mathrm{R}^{2}$} & \multicolumn{3}{|c|}{0.938} & & \\
\hline $\begin{array}{l}\text { France-specific holiday } \\
\text { dummy }\end{array}$ & No & No & No & No & No & Yes \\
\hline Origin-specific time trends & No & Yes & No & No & Yes & Yes \\
\hline Quantity $>0$ in all months & No & No & Yes & Yes & Yes & Yes \\
\hline Price on RHS & No & No & No & Yes & No & No \\
\hline $\mathrm{N}$ & 18,768 & 103,224 & 8,496 & 8,496 & 46,728 & 46,728 \\
\hline \multicolumn{7}{|c|}{ 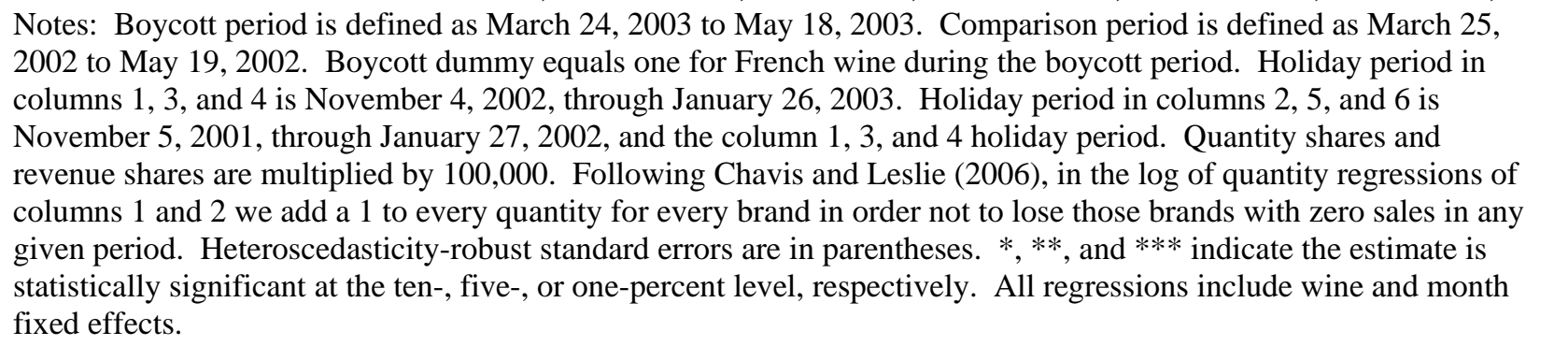 } \\
\hline
\end{tabular}


Figure 1

Regression Residuals from French Revenue Share on Holiday Dummy and Time Trend

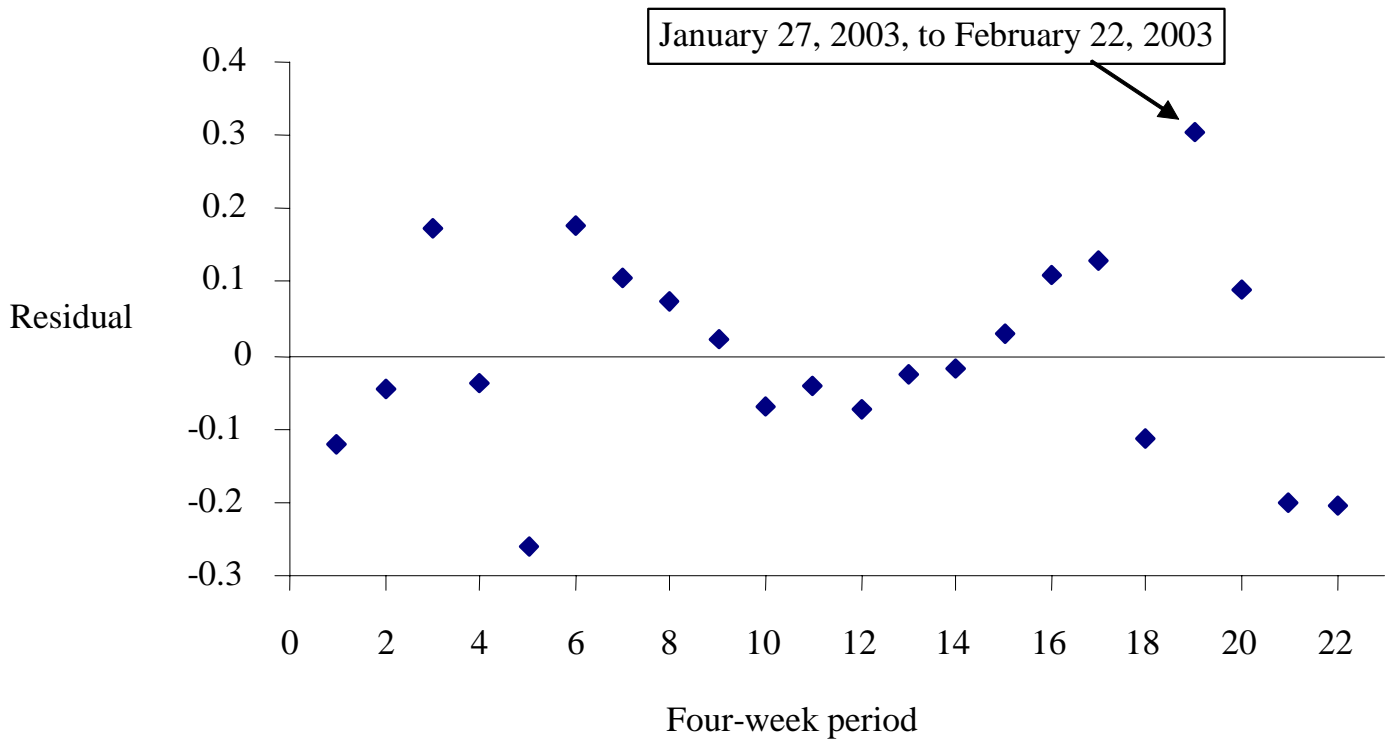

Note: Regression equation is $W_{t}=3.33+0.49 * H_{t}-0.04 * T_{t}$. Standard errors are 0.069 for the intercept, 0.070 for the holiday dummy, and 0.005 for the time trend. All are statistically significant at the 1 percent level. 


\section{Appendix}

Appendix Table 1

\section{Descriptive Statistics}

\begin{tabular}{|c|c|c|c|}
\hline & Observations & $\begin{array}{l}\text { Means and } \\
\text { Standard } \\
\text { Deviations } \\
\text { (2) }\end{array}$ & Medians \\
\hline \multicolumn{4}{|c|}{ Aggregated Data-Boycott and Comparison Periods } \\
\hline French revenue share & 8 & $\begin{array}{c}2.83 \\
(0.392)\end{array}$ & 2.85 \\
\hline French quantity share & 8 & $\begin{array}{c}2.55 \\
(0.344)\end{array}$ & 2.58 \\
\hline \multicolumn{4}{|l|}{ Aggregated Data-All Months } \\
\hline French revenue share & 22 & $\begin{array}{c}3.03 \\
(0.375)\end{array}$ & 3.02 \\
\hline French quantity share & 22 & $\begin{array}{c}2.71 \\
(0.311)\end{array}$ & 2.71 \\
\hline \multicolumn{4}{|c|}{ Individual Brand Data-Boycott and Comparison Periods } \\
\hline Revenue share*100,000 & 18,768 & $\begin{array}{c}21.31 \\
(165.24)\end{array}$ & 0.061 \\
\hline Quantity & 18,768 & $\begin{array}{c}7,758 \\
(64,791)\end{array}$ & 15 \\
\hline Quantity $>0$ in all months & 8,496 & $\begin{array}{c}16,731 \\
(95,076)\end{array}$ & 373 \\
\hline $\ln$ (Quantity) & 18,768 & $\begin{array}{c}3.32 \\
(3.38)\end{array}$ & 2.77 \\
\hline $\ln$ (Quantity) $>0$ in all months & 8,496 & $\begin{array}{c}6.14 \\
(2.58)\end{array}$ & 5.92 \\
\hline Quantity share*100,000 & 18,768 & $\begin{array}{c}21.31 \\
(177.93)\end{array}$ & 0.039 \\
\hline Price & 11,860 & $\begin{array}{l}12.39 \\
(9.12)\end{array}$ & 9.99 \\
\hline $\ln$ (Price) & 11,860 & $\begin{array}{c}2.36 \\
(0.533)\end{array}$ & 2.30 \\
\hline \multicolumn{4}{|l|}{ Individual Brand Data-All Months } \\
\hline Revenue share*100,000 & 103,224 & $\begin{array}{c}21.31 \\
(165.87)\end{array}$ & 0.057 \\
\hline Quantity & 103,224 & $\begin{array}{c}7,954 \\
(67,943)\end{array}$ & 14 \\
\hline Quantity $>0$ in all months & 46,728 & $\begin{array}{c}17,312 \\
(99,957)\end{array}$ & 409 \\
\hline $\ln$ (Quantity) & 103,224 & $\begin{array}{c}3.33 \\
(3.40)\end{array}$ & 2.71 \\
\hline $\ln ($ Quantity) $>0$ in all months & 46,728 & $\begin{array}{c}6.22 \\
(2.55)\end{array}$ & 6.02 \\
\hline Quantity share*100,000 & 103,224 & $\begin{array}{c}21.31 \\
(180.48)\end{array}$ & 0.038 \\
\hline Price & 64,754 & $\begin{array}{l}12.31 \\
(9.05)\end{array}$ & 9.95 \\
\hline $\ln$ (Price) & 64,754 & $\begin{array}{c}2.35 \\
(0.534) \\
\end{array}$ & 2.30 \\
\hline
\end{tabular}




\section{Appendix Table 2}

\section{Estimated Boycott Effect Using Four-Month Boycott Period and Observations with Strictly Positive Quantities (Table 2)}

\begin{tabular}{|c|c|c|c|c|}
\hline & $\begin{array}{c}\text { Boycott and } \\
\text { Comparison } \\
\text { Periods } \\
\text { (1) }\end{array}$ & $\begin{array}{c}\text { Boycott and } \\
\text { Comparison } \\
\text { Periods } \\
\text { (2) }\end{array}$ & $\begin{array}{c}\text { Entire } \\
\text { 22-Month } \\
\text { Period } \\
\text { (3) }\end{array}$ & $\begin{array}{c}\text { Entire } \\
\text { 22-Month } \\
\text { Period } \\
\text { (4) }\end{array}$ \\
\hline \multicolumn{5}{|c|}{ Dependent Variable - Revenue Share } \\
\hline Boycott dummy & $\begin{array}{l}-1.20 * * * \\
(0.390)\end{array}$ & & $\begin{array}{l}-1.23 \\
(1.08)\end{array}$ & $\begin{array}{c}1.09 \\
(1.31)\end{array}$ \\
\hline Adjusted $\mathrm{R}^{2}$ & 0.981 & & 0.979 & 0.979 \\
\hline \multicolumn{5}{|l|}{ Dependent Variable - $\ln ($ Quantity) } \\
\hline Boycott dummy & $\begin{array}{l}-0.073 * * \\
(0.033)\end{array}$ & $\begin{array}{l}-0.064 * * \\
(0.032)\end{array}$ & $\begin{array}{c}0.113^{*} \\
(0.060)\end{array}$ & $\begin{array}{c}0.099 \\
(0.071)\end{array}$ \\
\hline Adjusted $\mathrm{R}^{2}$ & 0.924 & 0.927 & 0.920 & 0.920 \\
\hline \multicolumn{5}{|c|}{ Dependent Variable - Quantity Share } \\
\hline Boycott dummy & $\begin{array}{l}-0.486 \\
(0.536)\end{array}$ & & $\begin{array}{l}-1.02 \\
(1.01)\end{array}$ & $\begin{array}{c}0.952 \\
(1.24)\end{array}$ \\
\hline Adjusted $\mathrm{R}^{2}$ & 0.985 & & 0.983 & 0.983 \\
\hline \multicolumn{5}{|l|}{ Dependent Variable - $\ln ($ Price $)$} \\
\hline Boycott dummy & $\begin{array}{c}0.008 \\
(0.005)\end{array}$ & & & \\
\hline Adjusted $\mathrm{R}^{2}$ & 0.936 & & & \\
\hline France-specific holiday dummy & No & No & No & Yes \\
\hline Origin-specific time trends & No & No & Yes & Yes \\
\hline Quantity $>0$ & Yes & Yes & Yes & Yes \\
\hline Price on RHS & No & Yes & No & No \\
\hline $\mathrm{N}$ & 23,667 & 23,667 & 64,754 & 64,754 \\
\hline $\begin{array}{l}\text { Notes: Regressions include all ob } \\
\text { for those same brands may have ze } \\
\text { only brands with strictly positive } s \\
\text { correspond to Table } 2 \text {, columns } 3 \\
\text { May } 18,2003 \text {. Comparison perioc } \\
\text { dummy equals one for French win } \\
2 \text { is November } 4,2002 \text {, through Ja } \\
\text { November } 5,2001 \text {, through Janual } \\
\text { shares and revenue shares are mult } \\
\text { log of quantity regressions we add } \\
\text { brands with zero sales in any give } \\
\text { parentheses. *, **, and } * * * \text { indica } \\
\text { one-percent level, respectively. A }\end{array}$ & $\begin{array}{l}\text { rvations with str } \\
\text { sales in some n } \\
\text { es over the entir } \\
\text { rough } 6 \text {. Boycot } \\
\text { s defined as Jan } \\
\text { during the boyce } \\
\text { lary } 26,2003 \text {. I } \\
27,2002 \text {, and th } \\
\text { lied by } 100,000 \\
1 \text { to every quan } \\
\text { period. Heterose } \\
\text { the estimate is s } \\
\text { regressions incl }\end{array}$ & $\begin{array}{l}\text { ctly positive sa } \\
\text { nonths, rather tl } \\
\text { e period of anal } \\
\text { t period is defir } \\
\text { lary } 28,2002 \text { tc } \\
\text { tt period. Holi } \\
\text { Ioliday period i } \\
\text { e column } 1 \text { and } \\
\text { Following Ch } \\
\text { ity for every br } \\
\text { edasticity-robu } \\
\text { tatistically sign } \\
\text { Ide wine and } \mathrm{m}\end{array}$ & $\begin{array}{l}\text { s, even thoug } \\
\text { n the Table } 2 \\
\text { is. Columns } \\
\text { d as January } 2 \\
\text { May } 19,2002 \\
\text { y period in cc } \\
\text { columns } 3 \text { an } \\
\text { holiday peric } \\
\text { is and Leslie } \\
\text { d in order no } \\
\text { standard erro } \\
\text { cant at the te } \\
\text { th fixed effec }\end{array}$ & $\begin{array}{l}\text { bservations } \\
\text { ressions of } \\
\text { rrough } 4 \\
2003 \text { to } \\
\text { oycott } \\
\text { mns } 1 \text { and } \\
\text { is } \\
\text { Quantity } \\
\text { 06), in the } \\
\text { lose those } \\
\text { rre in } \\
\text { five-, or }\end{array}$ \\
\hline
\end{tabular}




\section{Appendix Table 3}

\section{Estimated Boycott Effect Using Two-Month Boycott Period and Observations with Strictly Positive Quantities (Table 5)}

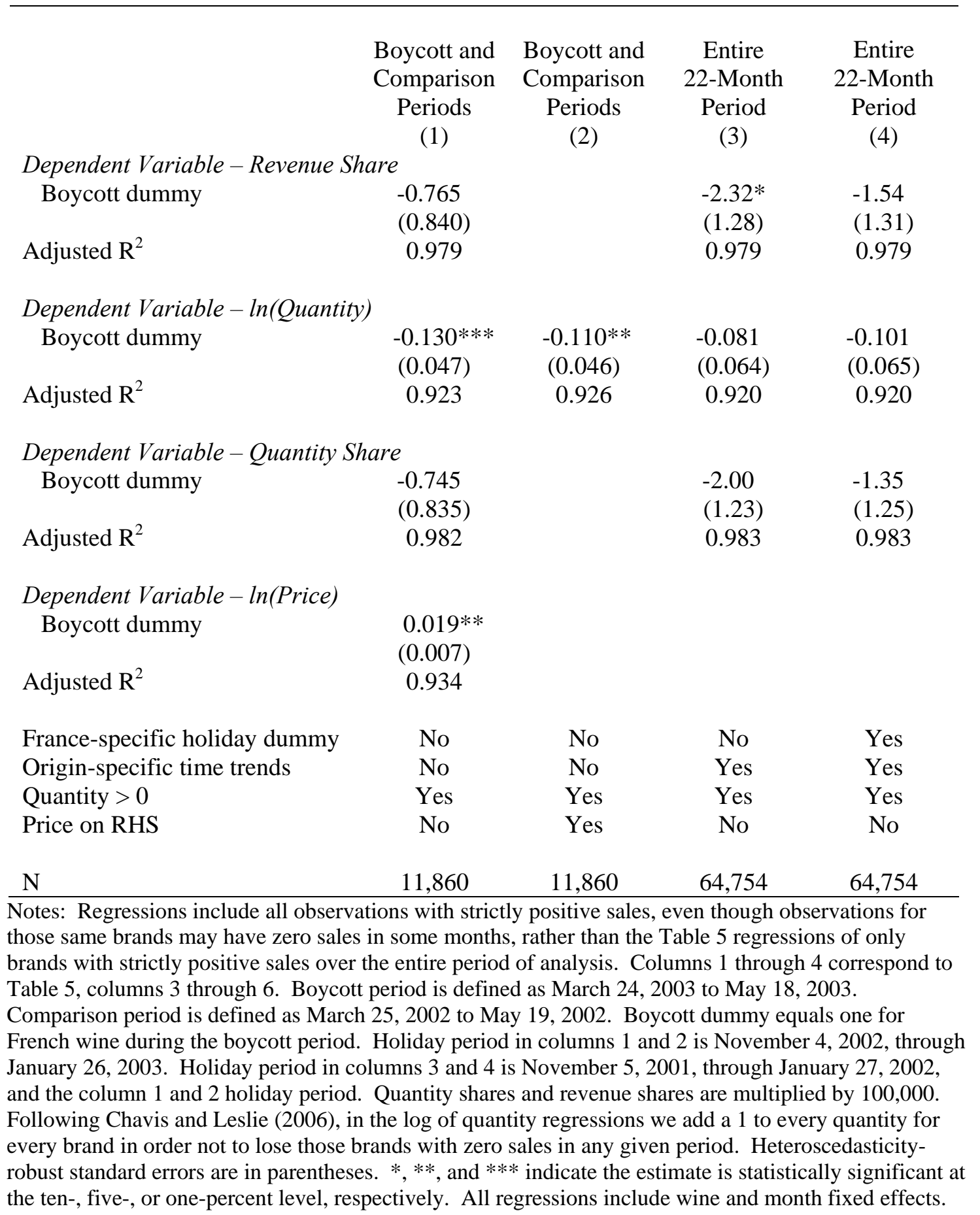




\title{
Appendix Table 4 \\ Major Newspapers and Transcripts
}

\author{
Major Newspapers (excluding non-U.S. newspapers) \\ The Atlanta Journal and Constitution \\ The New York Times \\ The Baltimore Sun \\ The Boston Globe \\ The Boston Herald \\ The Buffalo News \\ The Charlotte Observer \\ Chicago Sun-Times \\ Chicago Tribune \\ Newsday (New York, NY) \\ Omaha World Herald \\ The Orange County Register \\ The Oregonian \\ Orlando Sentinel \\ The Philadelphia Daily News \\ The Christian Science Monitor \\ The Philadelphia Inquirer \\ Pittsburgh Post-Gazette \\ The Columbus Dispatch \\ The Courier-Journal (Louisville, Kentucky) \\ The Plain Dealer \\ Rocky Mountain News \\ Daily News (New York) \\ Sacramento Bee \\ The Dallas Morning News \\ Saint Paul Pioneer Press \\ The Denver Post \\ San Antonio Express-News \\ Detroit Free Press \\ San Diego Union-Tribune \\ The Detroit News (Michigan) \\ Fort Worth Star-Telegram \\ The San Francisco Chronicle \\ The Hartford Courant \\ The Houston Chronicle \\ The Idaho Statesman (Boise) \\ The Indianapolis Star (Indiana) \\ Journal of Commerce \\ The Kansas City Star \\ Los Angeles Times \\ Miami Herald \\ The Milwaukee Journal Sentinel \\ San Jose Mercury News \\ The Seattle Times \\ St. Louis Post-Dispatch \\ St. Petersburg Times \\ Star Tribune (Minneapolis MN) \\ Sun-Sentinel (Fort Lauderdale) \\ The Tampa Tribune \\ The Times-Picayune \\ USA Today \\ The Washington Post
}

The Myrtle Beach Sun-News

\section{Transcripts (excluding non-U.S. transcripts)}

ABC News Transcripts
Burrelle’s Transcripts
CBS News Transcripts
The Charlie Rose Show
CNBC/Dow Jones Business Video
CNBC News
CNN
CNN Financial All
CNN Financial Network Transcripts
CNN International
CQ Congressional Testimony
CQ Transcriptions
FD (Fair Disclosure) Wire

FDCH News Service Capitol Report

Federal News Service

Fox News Network

MSNBC

National Narrowcast Network Transcripts

National Public Radio

NBC News

The NewsHour with Jim Lehrer

The Nightly Business Report

Presidential Campaign Press Materials

Video Monitoring Services of America

(formerly Radio TV Reports)

Notes: For newspapers, articles and editorials were counted. Letters were excluded. All versions of the same article were counted if they appeared in different newspapers but only one was counted if different versions appeared in different editions of the same newspaper. For transcripts, transcripts and teasers were counted. If a show was aired on two different channels or networks, it was counted for each appearance. If the boycott was mentioned in different segments of the same show, it was counted only once. If a teaser for segment of a show appeared during the airing of the show, it was not counted. 